\title{
Rafting technique without bone grafting in reverse Hill-Sachs lesions
}

\author{
Ters Hill-Sachs lezyonlarında kemik greftlemesi olmaksızın rafting tekniği
}

\author{
Meriç Çırpar, MD., ${ }^{1}$ Birhan Oktaş, MD., ${ }^{1}$ Bülent Dağlar, MD. ${ }^{2}$ \\ 1Department of Orthopedics and Traumatology, Medical Faculty of Kırıkkale University, Kırıkkale, Turkey \\ ${ }^{2}$ Department of Orthopedics and Traumatology, Güven Hospital, Ankara, Turkey
}

\begin{abstract}
In this article, we report a case of bilateral posterior shoulder instability, having reverse Hill-Sachs lesions of 25 to $50 \%$ of the articular surface on the right side, and of $50 \%$ on the left side. The defects were anatomically reconstructed after tuberculum minus osteotomy by elevation of the articular surface and buttressing with raft screws without graft usage. Early rehabilitation with pendulum shoulder exercises was started at third postoperative day. At postoperative sixth week, patient had full range of motion without instability and pain. At postoperative $18^{\text {th }}$ month, the patient had normal physical examination and the constant shoulder score was 86 , which was $92.4 \%$ of the age- and gender-matched population. Rafting technique without bone grafting may be a treatment alternative with satisfactory clinical results for medium to large sized reverse Hill-Sachs lesions of posterior shoulder instability.
\end{abstract}

Keywords: Bone grafting; joint instability; reconstruction; reverse Hill-Sachs lesion; shoulder dislocation.

Bilateral simultaneous shoulder dislocation is a rare injury. It usually occurs secondary to epileptic seizure and most of them are posterior. ${ }^{[1,2]}$ Posterior shoulder dislocations are frequently associated with an anterior impression fracture of the humeral head. The size of this impression defect, the reverse Hill-Sachs or the McLaughlin lesion designates the treatment. It is well-documented that posterior capsular shift and posterior Bankart repair do not effectively address the instability with engaging reverse Hill-Sachs lesions. ${ }^{[3,4]}$ Conservative treatment is recommended for bony defects involving less than $20-25 \%$ of the humeral head..$^{[5,6]}$ For large defects which are greater than $45-50 \%$ of the head, hemi or total shoulder
$\ddot{O Z Z}$

Bu çalışmada, sağ tarafta eklem yüzeyinin \%25-50'si ve sol tarafta \%50'si kadar ters Hill-Sachs lezyonu olan çift taraflı bir posterior omuz instabilitesi olgusu bildirildi. Defektler tüberkulum minus osteotomisi sonrası eklem yüzeyinin yükseltilmesi ve greft kullanılmadan raft vidaları ile desteklenmesi yoluyla anatomik olarak yeniden yapılandırıldı. Ameliyat sonrası üçüncü günde pandüler omuz egzersizleri ile erken rehabilitasyona başland. Ameliyat sonrası altıncı haftada hastanın hareket açıklığı instabilite ve ağrı olmaksızın tam idi. Ameliyat sonrası 18. ayda hastanın fizik muayenesi normal ve constant omuz skoru yaş ve cinsiyet dengi popülasyonun \%92.4'ü olacak şekilde 86 idi. Kemik greftlemesi olmaksızın rafting tekniği, posterior omuz instabilitesinde orta ila büyük boyutlu ters Hill-Sachs lezyonlarında tatmin edici klinik sonuçları ile bir tedavi alternatifi oluşturabilir.

Anahtar sözcükler: Kemik greftlemesi; eklem instabilitesi; yeniden yapılandırma; ters Hill-Sachs lezyonu; omuz çıkığı.

arthroplasty is advised in the literature. ${ }^{[5,7,8]}$ Medium defects involving $20-50 \%$ of the humeral head can be treated by non-anatomical reconstructions of filling the defect by the subscapularis tendon (McLaughlin procedure) or the lesser tuberosity. ${ }^{[2,5]}$ Anatomic reconstruction procedures for this size of defects are structural allograft or autograft augmentation of the defect either after elevation of the impressed segment or by filling the defect. ${ }^{[2,9,10]}$

Rafting technique can be defined as the buttressing of a depressed osteochondral fragment with raft of screws or even Kirschner wires. ${ }^{[11,12]}$ This technique is described especially for depressed tibial plateau fractures. ${ }^{[13]}$

- Received: December 16, 2016 Accepted: January 05, 2017

- Correspondence: Meriç Çırpar, MD. Kırıkkale Üniversitesi Tıp Fakültesi Ortopedi ve Travmatoloji Anabilim Dalı, 71100 Kırıkkale, Turkey. Tel: +90 532 - 5909420 e-mail: drmeric@yahoo.com 

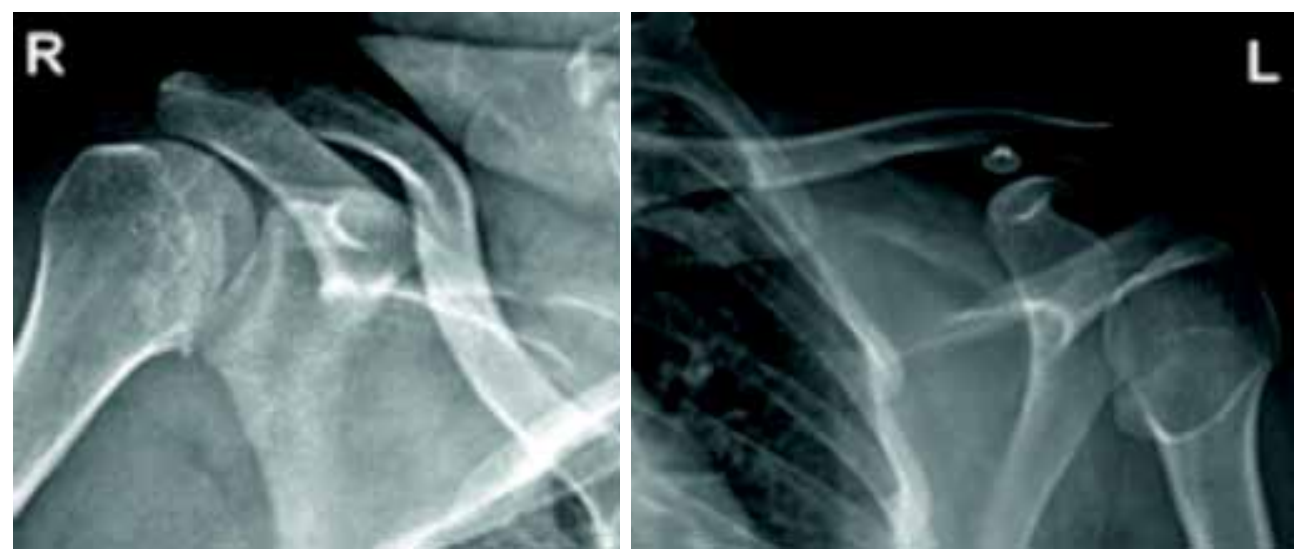

Figure 1. Anteroposterior radiogram of both shoulders at initial evaluation.

In this article, we report a case of bilateral posterior shoulder instability, with reverse Hill-Sachs lesions, which we treated by tuberculum minus osteotomy followed by elevation of the impressed osteochondral defect and supported by underpinning raft screw technique without grafting. We aim to underline the clinical outcomes of anatomical reconstruction of the sphericity of the humeral head and review advantages and disadvantages of the reported technique. ${ }^{[14]}$

\section{CASE REPORT}

A 32-year-old male patient was consulted by our clinic with bilateral shoulder pain and loss of motion after two episodes of epileptic seizure. The patient was semi-conscious when he was evaluated for shoulder pain. Only anteroposterior shoulder radiograms of both shoulder were present (Figure 1), and we could not get axillary lateral, trauma axillary lateral, Velpeau axillary lateral or lateral scapular Y view X-rays. We demonstrated posterior locked dislocations of both shoulders with large reverse Hill-Sachs lesions on computed tomography (CT) scans. Closed reduction was attempted under general anesthesia for both shoulders. Right shoulder was instable with abduction greater than $30^{\circ}$ and internal rotation greater than $10^{\circ}$ after closed reduction. Left shoulder was locked posteriorly and closed reduction was not possible.

On CT scans, the anterior head defect was measured to be between $25 \%$ and $50 \%$ of the articular surface of the head on the right side, and $50 \%$ on the left side (Figure 2).

The shoulder joints were reached through a deltopectoral approach with the patient in beachchair position. A tuberculum minus osteotomy beginning at the medial edge of the intertubercular
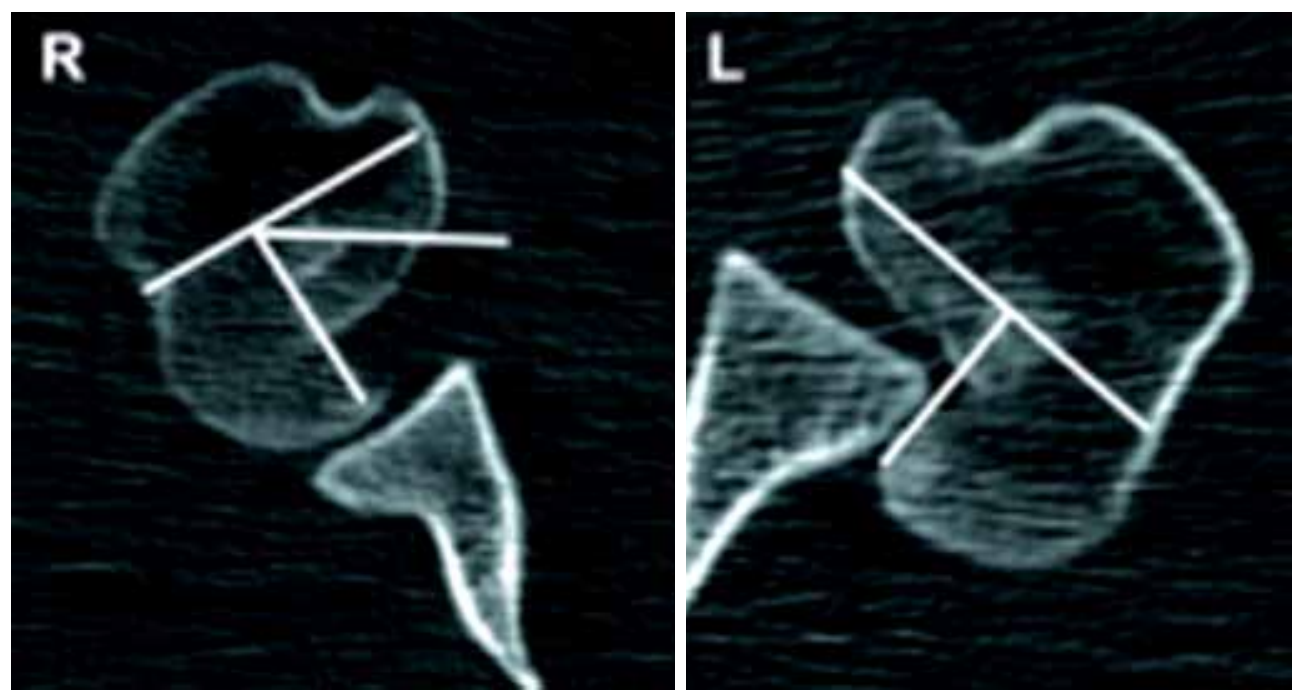

Figure 2. Axial computed tomography scanogram previewing extent of osteochondral defect on both humeral heads. 


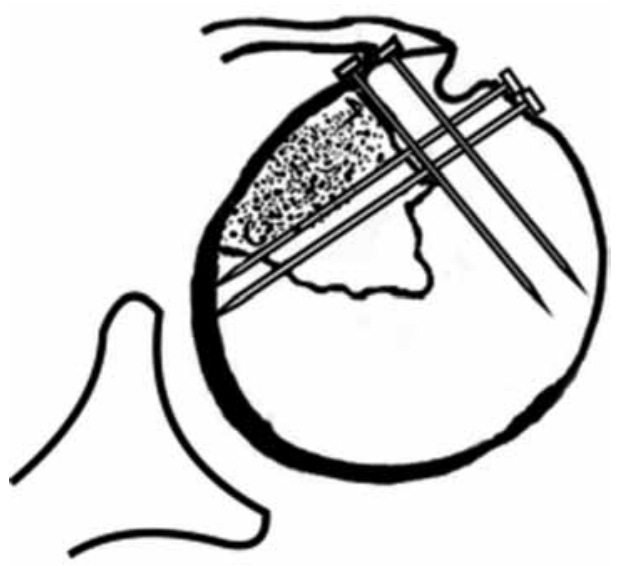

Figure 3. Schematic drawing showing buttressing of osteochondral fragment and fixation of tuberculum minus with screws.

sulcus extending medially was performed with a mini oscillating saw. The subscapularis was elevated with its insertion on osteotomized tuberculum minus. Anterior glenohumeral capsule was opened longitudinally and the humeral head with massive bony defect was visualized. The depressed articular surfaces were elevated with meticulous attention on the integrity of the fragments. On the left side, the elevated articular segment was fractured into two parts. On the right side, the elevated segment was buttressed with two lateral to medially oriented $3.5 \mathrm{~mm}$ cortical screws with raft screw technique used for depressed tibia plateau fractures (Figure 3). On the left side, the two fragments of the depressed articular surface was buttressed using two lateral to medially and a medial to laterally oriented $3.5 \mathrm{~mm}$ cortical screws. Tuberculum minus was reattached to its original place with two $3.5 \mathrm{~mm}$ cortical screws on both sides. The tuberculum minus and the insertion of the subscapularis tendon was reinforced using $5 \mathrm{~mm}$ titanium suture anchors on both sides. On intraoperative physical examination, we tested the stability of the shoulder and the fixation of the bony fragments.

Pendulum shoulder exercises were started at the third postoperative day when the soft tissue swelling subsided. The patient used shoulder sling for both shoulders for two weeks between the exercise periods. At the end of third postoperative week, rotator cuff strengthening exercises were started. At the end of sixth postoperative week, the patient had full range of motion (ROM) without instability and pain (Figure 4). The last control was at postoperative $18^{\text {th }}$ month with completely normal physical examination and without any complaints. At this control, the constant shoulder score was 86 , which was $92.4 \%$ of the age- and gendermatched population. On CT scans performed at $18^{\text {th }}$ month control, the defect was filled with bone and the head of the humerus was protecting its anatomical spherical shape (Figure 5). An informed consent was obtained from the patient.

\section{DISCUSSION}

In posterior shoulder dislocations, the reverse HillSachs or the McLaughlin lesion is the main cause of instability. For defects less than $25 \%$ of the articular surface of the head, reduction is usually satisfactory. ${ }^{[6]}$ For defects between $25-50 \%$ of the articular surface, McLaughlin subscapularis transfer to the defect or Neer modification of transfer of the tuberculum minus to the defect are recommended treatment choices. $^{[15]}$ For these medium sized defects, other surgical options are derotation osteotomy of the humerus and reconstruction of the head with allograft or autograft. ${ }^{[2,16,17]}$ Hemiarthroplasty may be performed for large defects involving more than $50 \%$ of the head, while total shoulder arthroplasty may be performed for large defects with glenoid destruction. ${ }^{[18]}$

Subscapularis transfer, tuberculum minus transfer and derotation osteotomy are techniques which deteriorate normal anatomy and biomechanics of the
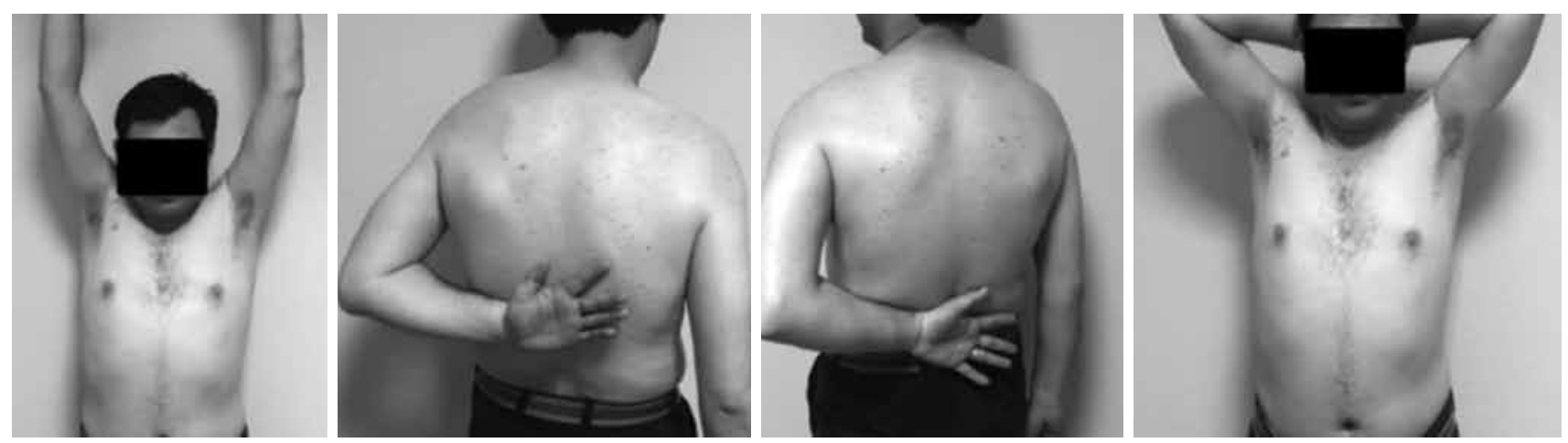

Figure 4. Shoulder range of motions at sixth postoperative week. 


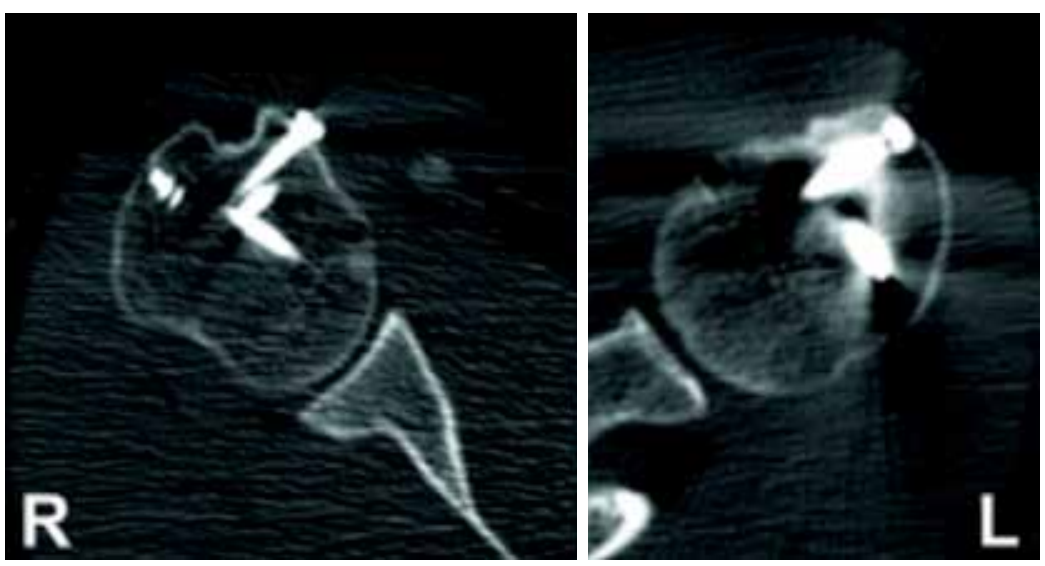

Figure 5. Computed tomography scans performed at $18^{\text {th }}$ month control. Defect was filled with bone and head of humerus was protecting its anatomical spherical shape.

shoulder joint. In subscapularis or tubercular transfer, the insertion of the tendon is medialized which decreases excursion length of the muscle tendon unit. Buckley et al. ${ }^{[19]}$ have underlined that biomechanical changes in subscapularis negatively affect the functional outcomes when compared with lesser tuberosity osteotomy in total shoulder osteotomy. Although satisfactory clinical results have been reported with modified McLaughlin technique, this biomechanicalalterationmay explain theloss of external and internal rotation in these series. ${ }^{[2,21]}$ In addition, Hawkins et al. ${ }^{[5]}$ report that, in late reconstructions and defects greater than $40 \%$ of the articular segment, subscapularis transfer may result with insufficiency, which may need shoulder joint arthroplasty. In their case series of six patients with locked posterior shoulder dislocation, Bock et al. ${ }^{[10]}$ have emphasized the importance of anatomic reconstruction to restore shoulder function and stability. The anatomic and biomechanical changes created by humeral derotation osteotomy seem to be related with loss of ROM in all planes, especially in external rotation in Porteous and Miller's study. ${ }^{[22]}$ In our case, although we performed a tubercular osteotomy, we securely reattached it without any anatomical and biomechanical change and obtained full ROM. Rafting technique we report here preserves the anatomic architecture of the humeral head and biomechanical properties of the musculature around the joint, which explains the almost excellent clinical outcome in our patient when compared with techniques altering shoulder joint characteristics.

Anatomic reconstruction of the reverse Hill-Sachs lesions for locked posterior shoulder dislocation with auto and allografts have been well-documented in the literature with satisfactory and encouraging results. ${ }^{[9,10,17,23,24]}$ Autogenous bone grafting is a widely applied surgical technique for various orthopedic conditions. However, obtaining bone graft from iliac crest has significant morbidity. Many minor and major complications as cutaneous nerve damage, persistent pain and discomfort, infection, hematoma and seroma of the wound, arterial injury, ureteral injury, herniation, fracture, pelvic instability, cosmetic defects, hematoma and tumor transplantation have been reported in different studies. ${ }^{[25,26]}$ Allografts have the risk of transmission of disease. ${ }^{[27]}$ Buttressing the osteochondral fragments without any form of bone grafts reduces the risk of these complications. Biomechanical characteristics and high resistance to local depression loads for raft screw constructs and their clinical outcomes have been shown for split depression fractures of the tibial plateau. ${ }^{[13,14]}$ Banerjee et.al. ${ }^{[24]}$ reported satisfactory results with underpinning raft technique for reverse Hill-Sachs lesions. In contrast to our technique, they fill the void created by elevation of the osteochondral fragments with allomatrix bone graft putty before providing subchondral support with cannulated screws. However, it is biomechanically proven in tibial plateau fractures that stiffness of the raft construct does not change with addition of bone graft. ${ }^{[14]}$ According to our results, we also think that rafting technique provides adequate stiffness without grafting for reverse HillSachs lesions. It is obvious that raft construct does not encounter mechanical loads as tibial plateau in the shoulder region. Thus, its biomechanical stiffness and resistance to local depression of the elevated osteochondral fragment would be high enough to begin active ROM exercises as shown for our patient. This is an advantage for early rehabilitation and 
enhanced functional recovery. We also demonstrated the survival of the reduction until bone healing is completed.

This study has an encouraging result for treatment of reverse Hill-Sachs lesions in posterior shoulder instability. However, it has some limitations. First of all, the number of cases should be increased to support scientific data about the technique. In addition, the technique also needs to be supported by biomechanical studies.

In conclusion, rafting technique without bone grafting may be a treatment alternative with satisfactory clinical results for medium to large sized reverse Hill-Sachs lesions of posterior shoulder dislocations.

\section{Declaration of conflicting interests}

The authors declared no conflicts of interest with respect to the authorship and/or publication of this article.

\section{Funding}

The authors received no financial support for the research and/or authorship of this article.

\section{REFERENCES}

1. Şanel S, Şencan S, Öçgüder A, Solakoğlu C. Bilateral, locked, recurrent anterior shoulder dislocation: case report. Eklem Hastalik Cerrahisi 2015;26:52-5.

2. Elmalı N, Taşdemir Z, Sağlam F, Gülabi D, Baysal Ö. Onestage surgical treatment of neglected simultaneous bilateral locked posterior dislocation of shoulder: a case report and literature review. Eklem Hastalik Cerrahisi 2015;26:175-80.

3. Burkhart SS, De Beer JF. Traumatic glenohumeral bone defects and their relationship to failure of arthroscopic Bankart repairs: significance of the inverted-pear glenoid and the humeral engaging Hill-Sachs lesion. Arthroscopy 2000;16:677-94.

4. Bigliani LU, Pollock RG, McIlveen SJ, Endrizzi DP, Flatow EL. Shift of the posteroinferior aspect of the capsule for recurrent posterior glenohumeral instability. J Bone Joint Surg [Am] 1995;77:1011-20.

5. Hawkins RJ, Neer CS, Pianta RM, Mendoza FX. Locked posterior dislocation of the shoulder. J Bone Joint Surg [Am] 1987;69:9-18.

6. Cicak N. Posterior dislocation of the shoulder. J Bone Joint Surg [Br] 2004;86:324-32.

7. Page AE, Meinhard BP, Schulz E, Toledano B. Bilateral posterior fracture-dislocation of the shoulders: management by bilateral shoulder hemiarthroplasties. J Orthop Trauma 1995;9:526-9.

8. Cheng SL, Mackay MB, Richards RR. Treatment of locked posterior fracture-dislocations of the shoulder by total shoulder arthroplasty. J Shoulder Elbow Surg 1997;6:11-7.

9. Gerber C, Lambert SM. Allograft reconstruction of segmental defects of the humeral head for the treatment of chronic locked posterior dislocation of the shoulder. J Bone Joint Surg [Am] 1996;78:376-82.

10. Bock $\mathrm{P}$, Kluger R, Hintermann B. Anatomical reconstruction for Reverse Hill-Sachs lesions after posterior locked shoulder dislocation fracture: a case series of six patients. Arch Orthop Trauma Surg 2007;127:543-8.

11. Beris AE, Soucacos PN, Glisson RR, Seaber AV, Urbaniak JR. Load tolerance of tibial plateau depressions reinforced with a cluster of K-wires. Bull Hosp Jt Dis 1996;55:12-5.

12. Yoon YC, Oh JK, Oh CW, Sahu D, Hwang JH, Cho JW. Inside out rafting K-wire technique for tibial plateau fractures. Arch Orthop Trauma Surg 2012;132:233-7.

13. Martin FO, de Menezes SS, Chiba AK, Langhi DM Jr, Nardozza LM, Chiattone CS, et al. RHD gene polymorphisms in alloimmunized RhD-negative individuals with high rate of racial admixture. Transfus Apher Sci 2013;48:113-6.

14. Atik OŞ. Are all case reports worth publishing? Eklem Hastalik Cerrahisi 2016;27:61.

15. Finkelstein JA, Waddell JP, O’Driscoll SW, Vincent G. Acute posterior fracture dislocations of the shoulder treated with the Neer modification of the McLaughlin procedure. J Orthop Trauma 1995;9:190-3.

16. Connor PM, Boatright JR, D'Alessandro DF. Posterior fracture-dislocation of the shoulder: treatment with acute osteochondral grafting. J Shoulder Elbow Surg 1997;6:480-5.

17. Khayal T, Wild M, Windolf J. Reconstruction of the articular surface of the humeral head after locked posterior shoulder dislocation: a case report. Arch Orthop Trauma Surg 2009;129:515-9.

18. Wooten C, Klika B, Schleck CD, Harmsen WS, Sperling JW, Cofield RH. Anatomic shoulder arthroplasty as treatment for locked posterior dislocation of the shoulder. J Bone Joint Surg [Am] 2014;96:19.

19. Buckley T, Miller R, Nicandri G, Lewis R, Voloshin I. Analysis of subscapularis integrity and function after lesser tuberosity osteotomy versus subscapularis tenotomy in total shoulder arthroplasty using ultrasound and validated clinical outcome measures. J Shoulder Elbow Surg 2014;23:1309-17.

20. Spencer EE Jr, Brems JJ. A simple technique for management of locked posterior shoulder dislocations: report of two cases. J Shoulder Elbow Surg 2005;14:650-2.

21. Banerjee M, Balke M, Bouillon B, Wafaisade A, Helm P, Akoto R, et al. Excellent results of lesser tuberosity transfer in acute locked posterior shoulder dislocation. Knee Surg Sports Traumatol Arthrosc 2013;21:2884-8.

22. Porteous MJ, Miller AJ. Humeral rotation osteotomy for chronic posterior dislocation of the shoulder. J Bone Joint Surg [Br] 1990;72:468-9.

23. Ivkovic A, Boric I, Cicak N. One-stage operation for locked bilateral posterior dislocation of the shoulder. J Bone Joint Surg [Br] 2007;89:825-8.

24. Banerjee S, Singh VK, Das AK, Patel VR. Anatomical reconstruction of reverse hill-sachs lesions using the underpinning technique. Orthopedics 2012;35:752-7.

25. Kim DH, Rhim R, Li L, Martha J, Swaim BH, Banco RJ, Jenis LG, et al. Prospective study of iliac crest bone graft harvest site pain and morbidity. Spine J 2009;9:886-92.

26. Dimitriou R, Mataliotakis GI, Angoules AG, Kanakaris NK, Giannoudis PV. Complications following autologous bone graft harvesting from the iliac crest and using the RIA: a systematic review. Injury 2011;42:3-15.

27. Palmer SH, Gibbons CL, Athanasou NA. The pathology of bone allograft. J Bone Joint Surg [Br] 1999;81:333-5. 